Шиирас Шарунас Альфонсович д-р пед. наук, доцент, доцент Литовский университет спорта

г. Каунас, Литовская Республика Уипурене Айсте Барбора д-р пед. наук, лектор Литовский университет спорта Университет Витаутаса Великого г. Каунас, Литовская Республика

DOI $10.21661 / R-473448$

\title{
PRE-COMPETITION STRESS FOR ATHLETES AT THE LITHUANIAN SPORTS UNIVERSITY
}

Аннотация: в представленной работе обращзается внимание на предстартовый стресс спортсменов Литовского университета спорта. Спортивные результаты определяются многими факторами, но одним из главных является стресс перед соревнованием. Несмотря на то, что стресс является значительным во всех областях человеческой деятельности, он еще более значим в спортивном мире, поскольку спортсмену требуется максимальная работа для достижения как умственных, так и физических спортивных результатов.

Ключевые слова: спортсмен, предстартовый стресс.

Abstract: in this paper, attention is paid to pre-competition stress for athletes at the Lithuanian Sports University. Sport results are affected by lots of factors, but one of the main factors is pre-competition stress. Although stress is significant in all fields of the human activity, it is even more significant in the world of sport because an athlete needs the maximum psychical and physical efforts to reach a sport result.

Keywords: athletes, prie-competition stress. 
As athletes encounter lots of complicated situations during the sport activity and sport activity takes place under difficult conditions of trainings and competitions, special stability of the athlete's psyche is necessary for this kind of activity. Taking this into account, psychological preparation is necessary for every athlete. In the opinion of most coaches and athletes, psychological preparation can determine the success of the sport activity. Scientific research shows: the higher is the psychological competence of athletes, the fewer mistakes they make during the competition fight, defeat various psychological barriers more effectively, understand their states more clearly and can solve different problems more rationally [2]. Thus, attention has been paid more and more often recently that a sport result also depends on the psychological features of an athlete and his/her ability to cope with pre-competition stress $[1 ; 3]$. It was revealed that the inability to cope with pre-competition stress could cause a lot of negative consequences to athletes including lower capability, dissatisfaction with the activity and termination of the sport activity [4]. However, research confirms that negligible pre-competition stress does not prevent an athlete from reaching good results, but it is necessary to fight against constant stress and its long-lasting state [1;2]. It is especially important for every coach working with an athlete of any level would be able to help to defeat this state or at least inhibit it a little in order to avoid its negative impact on sport results [3]. These scientific discussions only encourage developing research about pre-competition stress of athletes because we were unable to find any papers reviewing the peculiarities of pre-competition stress in athletes of individual and team sports.

Organising of the research. $9522 \pm 28$-year-old sport-doing students of the Lithuanian Sports University took part in the survey. All the researched were divided into two groups according to the kinds of sport: athletes of individual (14 boxers, 12 sprinters and 13 stayers) and team (21 basketball players, 24 football players and 11 volleyball players) sports. The survey took place an hour before the competition. In order to reach the goal, the thermometer methodology by J. Kiselev [5] was used with the purpose to determine the experienced subjective level of realized stress before the competition. 
Results. By applying the «Thermometer» by J. Kiselev, the statistically reliable difference $(\chi 2=8,99 ; \mathrm{p}<0,05)$ according to the realized pre-competition stress level was determined in the athletes of individual and team sports from the Lithuanian Sport University. The results of the research revealed that athletes of individual sports suffered from higher-level stress compared with athletes of team sports. It can be noted athletes evaluate stress suffered an hour before the competition in different ways. For example, athletes of individual sports evaluate their pre-competition stress level (48,7 per cent) as high more often.

Table 1

Distribution of the researched according to pre-competition stress

(in numbers and per cent)

\begin{tabular}{|c|c|c|c|c|}
\hline \multirow{2}{*}{ Researched } & \multicolumn{3}{|c|}{ Pre-competition stress level } & \multirow{2}{*}{$\begin{array}{l}\text { Significance of criterion } \\
\chi^{2} \text { and reliability level }\end{array}$} \\
\hline & high & average & low & \\
\hline $\begin{array}{l}\text { Athletes of individual } \\
\text { sports } n=39\end{array}$ & $\begin{array}{c}19 \\
(48,7)\end{array}$ & $\begin{array}{c}11 \\
(28,2)\end{array}$ & $\begin{array}{c}9 \\
(23,1)\end{array}$ & \multirow{2}{*}{$\begin{array}{c}8,99 \\
\mathrm{p}<0,05\end{array}$} \\
\hline $\begin{array}{l}\text { Athletes of team sports } \\
\mathrm{n}=56\end{array}$ & $\begin{array}{c}11 \\
(19,7)\end{array}$ & $\begin{array}{c}25 \\
(44,6) \\
\end{array}$ & $\begin{array}{c}20 \\
(35,7) \\
\end{array}$ & \\
\hline
\end{tabular}

Meanwhile, 44,6 per cent of athletes of team sports indicate their pre-competition stress level is average and just 19,7 per cent of them say it is high. To sum up the statistical indicators of pre-competition stress suffered by the athletes of the Lithuanian Sport University, it can be stated that athletes of team sports have better abilities of coping with pre-competition stress before the competition.

Conclusions. The results obtained with the help of the research methodology by J. Kiselev allow stating that the athletes of individual sports from the Lithuanian Sport University suffer from statistically reliably higher pre-competition stress compared with the athletes of team sports $(\mathrm{p}<0,05)$.

\section{Сиисок литературы}

1. Jennings, R. A., Henderson, C. S., Erla, M. A., Abraham, S., Gillum, D. (2018). Stress Coping Behaviors of Faith-Based College Non-Student Athletes vs. StudentAthletes // College Student Journal. - No. 52(2). - P. 245-257. 
2. Neil, R., Hanton, S., Mellalieu, S. D., Fletcher, D. (2011). Competition stress and emotions in sport performers: The role of further appraisals // Psychology of Sport and Exercise. - No. 4 (2). - P. 460-470.

3. Reed, S., Giacobbi Jr. P. R. (2004). The stress and coping responses of certified graduate athletic training students // Journal of Athletic Training. - No. 2 (39). - P. 193-199.

4. Tišma, M., Čokorilo, R. (2015). Identifying sources of stress in footballers and swimmers of both genders at different competition levels // Physical Education and Sport. - No. 2 (13). - P. 177-191.

5. Киселев Ю.Ю. Методики психодиагностики в спорте. - М.: Просвещение, 1990. 